\title{
A Descriptive study between Iraqi EFL Learners and English Native Speakers in Pronouncing English Vowels: A Contrastive Study
}

\author{
Assist. Inst. Furqan Abdul-Ridha Kareem Altaie \\ College of Education- University of Misan
}

furqan-altaie@uomisan.edu.iq

\section{Abstract:}

Iraqi speakers of English face some phonetic and phonological difficulties that are related with the production of different speech sounds especially English vowel sounds. The difficulty in producing these sounds is related to several matters. Firstly, the complex orthographic system of English. Secondly is the inconsistent relationship between spelling and pronunciation. Third shows the differences between the two different sound systems (Arabic and English). The regional differences and the effect of the native language on the second language can be considered as two of the real problems in pronunciation.

المستخلص

يواجه العراقيون متعلمين اللغة الانكليزية بعض المشاكل الصوتية. تتمثل هذه المشاكل في نطق أصوات

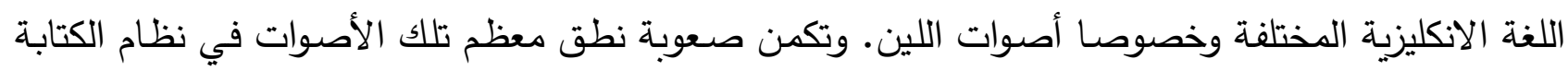

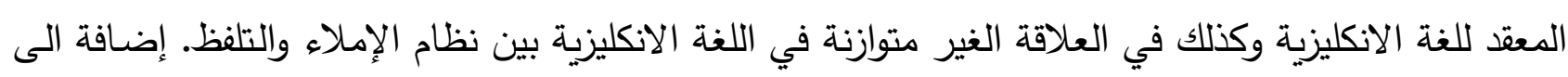

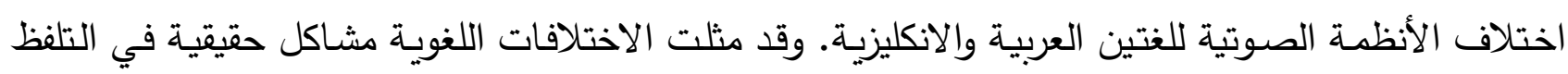
وخاصة في مجال تأثيرات اللغة الأم على اللغة الثانية.

\section{Introduction}

The most important part of learning English as a second language rests on pronunciation. Speaking is an important factor in learning English appropriately (Gussenhoven and Jacobs, 1998). This means that studying errors of English pronunciation is a valuable source to which provide information on student's errors. 
These help teachers to correct errors and improve the effectiveness in teaching English pronunciation. The problem of the study is that non -native speakers of English come across certain difficulties in producing speech sounds especially vowels. These difficulties appear among non-native speakers from the fact that the sound systems of English and Arabic are different in many ways. English vowel sounds are different from Arabic vowel sounds in number, in the way they are produced, and even many English vowels don't exist in Arabic sound system.

The objectives of the study are :

1-It aims to investigate the difficulties of English pronunciation chanced by Imari speakers when pronouncing English vowel sounds.

2 -The aim of this study is pedagogical because the study accounts the difficulties of English pronunciation and helps a great deal in understanding vowel sounds by giving some suggestions for learners and syllabus designers that help to improve pronunciation .

The hypothesis of the study are the following :

1-Iraqi Imari speakers of English will face difficulty in pronouncing or producing English vowel sounds .

2-They will face difficulty in producing diphthongs and triphthongs more than in producing pure vowels .

The study is limited to Iraqi Imari people and it is focused on the pronunciation of just vowel sounds .

\section{The Theoretical Part}

\subsection{The production of vowels}


Speech sounds are produced by obstructing with a body of moving air. Phoneticians describe a body of moving air used in speech production by the term airstream mechanism. Airstream mechanism can be defined as the way in which the airflow that provides the power for speech production is created. This airstream mechanism is called the pulmonic egressive airstream (Katamba , $1989: 2$ ) .

Pulmonic egressive airstream means the air that is created in the lungs and then goes out of the lungs up to the trachea and gets out through the mouth, or through the nose, or through both (Sethi and Dhamija , $2006: 2$ ) .

The air that is created in the lungs undergoes many different modifications in the upper stages of the respiratory tract, carried by the actions of the vocal folds and the articulatory organs before it acquires the quality of a speech sound (Daniel , I. $O, 2011: 6)$. Low , E $(2015: 21)$ explains that in order to produce a speech sound, the air from the lungs passes through the trachea to the larynx. In the larynx, the air passes through the vocal folds. If the vocal folds are open and there is no vibration, the sounds that come out are voiceless, while if the vocal folds come together and vibrate, the sounds that emerge are voiced. All vowels are voiced . Some consonants are voiced and the others are voiceless.

The sounds which the organs of speech are able of uttering are of two main types. The first type is called vowels and the second type is called consonants . From the phonetic point of view, consonants are the sounds that articulated by temporary closure in the airflow which passes from larynx to lips. The closure made by the articulators may be complete or partial . But vowels are the sounds that are articulated without any closure in the airstream (Roach , 2001: 74).

Crystal $(2008: 103)$ illustrates that consonants are sounds that articulated by a narrowing in the airflow so that the air is either completely blocked or partially 


\section{هجلة أبحاث هيسان، الجلد السابع عشر، العدد الرابع والثلاثون، كانون الأول، السنة 2021}

https://doi.org/10.52834/jmr.v17i34.82

to cause friction .Sethi and Dhamija (2006:14) show that in the production of vowels, there is no narrowing

of a degree that would cause audible friction. According to Shandera and Burleigh (2011:31) , vowels are produced without any obstruction of airstream . While consonants are produced with three degrees of closure : complete closure, close approximation and open approximation ( Carr , 1993 : 32).

Phonologically speaking, consonants occupy the onset and the coda positions in the syllable ; whereas, vowels occupy the nucleus position in the syllable. For example, the word (pear) /peə/ begins with a consonant and this consonant represents the onset of the syllable, followed by the diphthong which occupies the nucleus of the syllable (Casas , R.M, 2014:15). According to Abercrombie (1967:39) a vowel is the center or the main part of the syllable whereas a consonant represents the marginal part

Low, E (2015:24 )points out that consonants can be described by the following three main characteristics :

1-Voicing means whether the consonant sound is voiced or voiceless . It depends on the vibration of the vocal folds. If the vocal folds are vibrated, the sound produced is called voiced. If the vocal folds are not vibrated, the sound produced is called voiceless sound.

2-Manner of articulation means the way of how

the sound is produced There are several manners or ways for consonant production as shown in Katamba (1989: 6-7) . 


\section{1

This manner shows that the articulators come together in order to cut off the airstream . / p , b , t , d , k, g / are stops or plosives.

b-Fricative

It shows that the articulators come close to each other leaving a narrow space between them to allow air to pass between them and cause audible plosion (friction ). English fricatives are / $f, v \theta, \delta, s, z, \int, 3 /$.

c-Affricate

The articulators come together in order to cut off the airstream, then they separate from each other . / $t \int /$ and / $d_{3} /$ are affricates .

\section{d-Approximant}

The articulators are brought near each other but there is a great opening between them to allow air to escape without friction . / r, w , j, I / are approximants. e-Nasals

Nasals are sounds in which the velum is lowered and the air escapes through the nose. Nasal sounds are / $m, n, y$ / .

f-Lateral

A lateral sound is a sound which is produced when the air is cut off by the tongue so that it passes through the sides of the mouth . / I / is lateral .

3-Place of articulation means the place at which the sound is produced. There are several places for sound production (Cruttenden , 2014 :29).

a-Bilabial

The two lips are the main articulators. Bilabial sound can be defined as a sound which is produced by the two lips . / p,b,m / are bilabial sounds .

b-Dental 


\section{1
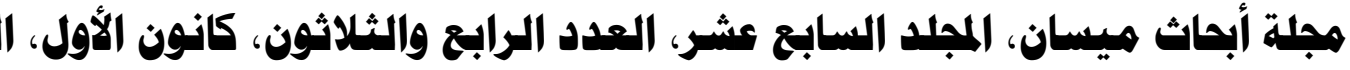

https://doi.org/10.52834/jmr.v17i34.82

Dental sound is a sound which is articulated by the tongue tip with the upper front teeth . / $\theta, ठ /$ are dentals.

c-Alveolar

Alveolar sound is a sound which is produced with the tongue tip and blade touch the alveolar ridge $. / s, z, t, d, n, I \quad /$ are alveolar sounds.

d-Post-alveolar

The blade of the tongue articulates with the back part of the alveolar-ridge./ $\int, 3$, $\mathrm{t} \int, \mathrm{d}_{3} /$ are post-alveolar sounds.

d-Retroflex

The tip of the tongue touches the alveolar-ridge $. / r /$ is a retroflex sound. e-Palatal

The front of the tongue articulates with the soft palate $. / \mathrm{j} /$ is a palatal sound f-Velar

It is a sound which is formed with the back of the tongue touching the soft palate $/ \mathrm{k}$ $, \mathrm{g}, \mathrm{y} /$ are velar sounds.

g-Glottal

It is a sound which is produced at the glottis . Glottis is the opening between the vocal folds . / $\mathrm{h} /$ is a glottal sound.

\subsection{The Description of vowels}

Katamba ( $1989: 8$ ) points out that vowels are more difficult to describe than consonants because there is no closure in the vocal tract during their production . There are three important features for vowel description. These features are shown 


\section{هبلة أبحاث هيسان، المبد السابع عشر، العدد الرابع والثلاثون، كانون الأول، السنة 2021}

https://doi.org/10.52834/jmr.v17i34.82

in

Skandera

and

Burleigh

(2005:32).

\subsubsection{Closeness / openness or tongue height}

It means the distance between the tongue and the palate. If the tongue is high, it is close to the palate. The produced vowel is called close vowel. If the tongue is low, it is open to the palate. This means that there is an open gap between the tongue and the palate. The produced vowel is called open vowel. Close vowels are / I, i: $v, \mathrm{u}:$ /. Open vowels are / æ, p, a: /. There are also three intermediate extremes or levels. If the tongue is in a half-high or a mid-high position, the resulted sound is a mid-close or a half-close vowel. If the tongue is in a mid-low or a half-low position, the resulted sound is a mid-open vowel or a half-open vowel. If the tongue is between half-high and half-low, the produced sound is a mid-vowel. Mid vowels are /e,,,$\Lambda$, ə, 3: /.

\subsubsection{Frontness /backness}

It refers to which part of the tongue is raised the highest. If the front part of the tongue is raised the highest, the resulted sound is a front vowel. If the back part of the tongue is raised the highest, the resulted sound is a back vowel. If the center of the tongue is raised the highest, the resulted sound is a central vowel.

Front vowels are / I , i: ,e, æ / .

Central vowels are $/ \partial, \Lambda, 3: /$.

Back vowels are /u: , , p, o: , a:/

\subsubsection{The shape of the lips}


The lips can be spread, neutral , or rounded . Roach (2009:13)states three cases. Spread, where the lips are away from each other. This is clearly seen in the production of vowel /i: / . Neutral, where the lips are in the normal shape as in the production of / e, $\Lambda, \partial /$. Rounded, where the lips are pushed forward as in the production of $/ \mathrm{u}: v,,: \mathrm{s}, \mathrm{p} /$.

\subsection{Cardinal vowels}

Roach (2009:12) notes that cardinal vowels are standard reference system . In order to describe the vowels of any language and compare the vowel systems of different languages more accurately, the British phonetician Daniel Jones discovered 18 reference points or vowels called the cardinal vowels . Cardinal vowels show the extremes of vowel quantity that the vocal tract is able to produce . It is so important to know that cardinal vowels are not sounds of a particular language, they are reference points or extremes by which we can describe all the vowels. They are of two different types : Primary and secondary (Shandera and Burleigh

$$
2005
$$

Roach (2009:12) points that primary cardinal vowels are usual to most European languages speakers ; while secondary cardinal vowels are the sounds that are less usual to the speakers of most European languages. Primary cardinal

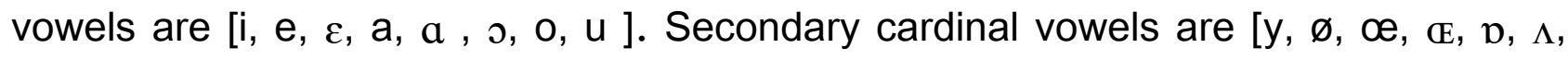
$\gamma, \mathrm{U}, \dot{\mathrm{z}}, \mathrm{u}]$. Primary cardinal vowels are eight in number, secondary cardinal vowels are ten in number. We can describe primary and secondary cardinal vowels according to 1-tongue height 2-part of the tongue 3-shape of lips (De ,A. 1999:

$$
12-13) \text {. }
$$

[i ] and [ u ] are close vowels, [ e ] and [o ] are close-mid vowels . [ $\varepsilon$ ] and [0 ] are open -mid vowels, [a ] and [a ] are open vowels . [a, o,o,u ] are back vowels . [a, $\varepsilon, e, i]$ are front vowels . [i ,e, $\varepsilon, a, a$ ] have unrounded lips . [0,o,u ] have rounded lips. Secondary cardinal vowels, [y, i, u, u ] are close vowels . [ø, 


\section{هبلة أبحاث هيسان، المبد السابع عشر، العدد الرابع والثلاثون، كانون الأول، السنة 2021}

https://doi.org/10.52834/jmr.v17i34.82

$\gamma$ ] are close-mid vowels . [œ] ] and [ $\Lambda$ ] are open -mid vowels . [๕ ] and [p] are

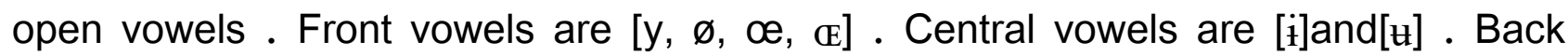
vowels are $[\mathfrak{p}, \Lambda, \mathfrak{u}, \mathrm{u}]$. Secondary cardinal vowels which have unrounded lips are $[y, \varnothing, \propto, \Subset, \dot{i}]$. While secondary cardinal vowels which have rounded lips are $[\mathrm{p}, \Lambda$, $\gamma$, $\mathrm{u}$, H ]

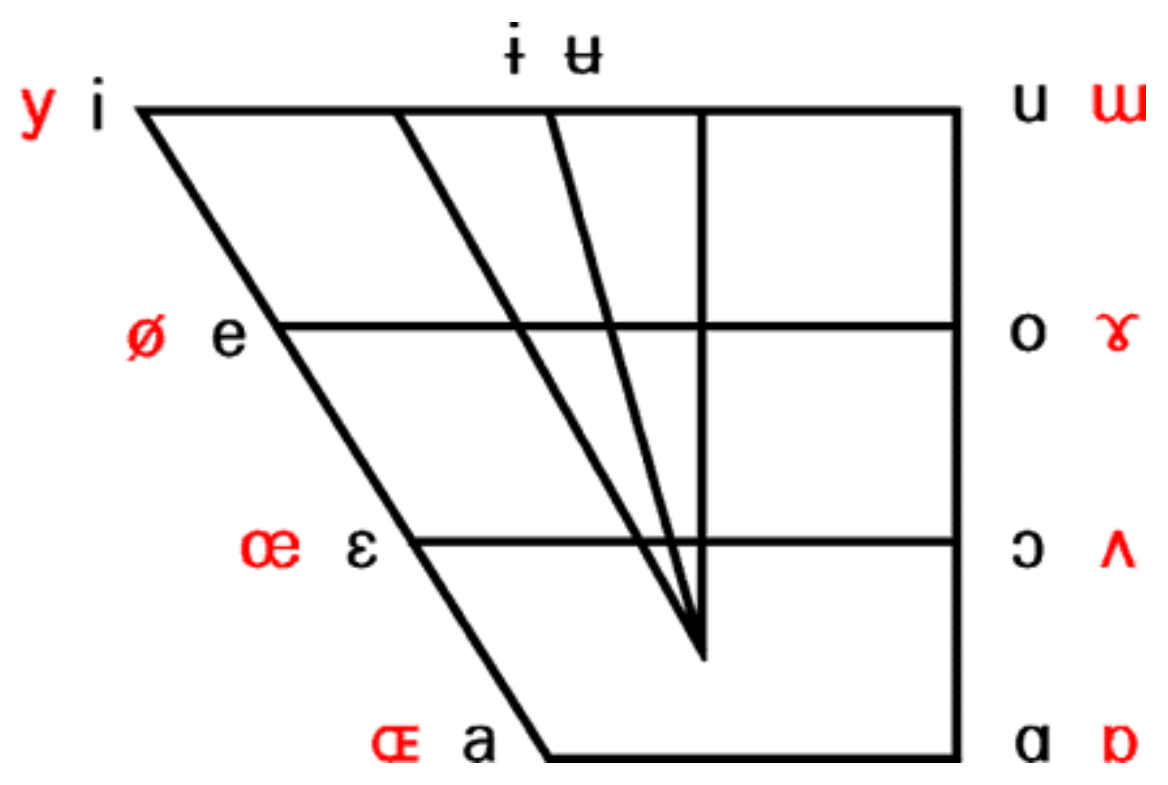

Figure(1): Cardinal vowels

\subsection{Classification of vowels}

Pure vowels can be defined as a vowel which remain constant and does not glide (Roach , $2009: 17$ ) .Through the production of pure vowels, the organs of speech remain motionless for a remarkable period of time. Vowels which have a 
consistent unchanging quality from the beginning of its production to the end are called pure vowels (Giegerich, 1992:

Birjandi and Nodoushan (2005:62) shows that there are two main kinds of vowels on the basis of their length: long vowels and short vowels. The distinction between them depends on the duration of time that the speakers spend in articulating or producing them. In producing long vowels, the time is longer than the time spent in articulating short vowels. Length is represented by putting a colon (:) after the sound . In British English, there are five long vowels.

1-/i:/ as in sheep / fi:p/

$2-/ 3: /$ as in fur $/ f_{3}: /$

$3-/ 0: /$ as in four / $\mathrm{f} \mathrm{0:} /$

$4-/ a: /$ as in car / $k a: /$

5-/u:/ as in boot / bu:t/

There are seven short vowels .

$1-/ \mathrm{I} /$ as in hit /hIt/

$2-/ \mathrm{e} /$ as in hen /hen/

$3-/ æ /$ as in hat / hæt/

$4-/$ ə/ as in ago / ㅁgəひ/

$5-/ \mho /$ as in book / bok/

$6^{-} / \wedge /$ as in bus $/ \mathrm{b} \wedge \mathrm{s} /$

$7-/ \mathrm{p} /$ as in hot /hot/ 


\section{هجلة أبحاث هيسان، الجبد السابع عشر، العدد الرابع والثلاثون، كانون الأول، السنة 2021}

\subsubsection{Pure Vowels}

Pure vowels can be described according to the three criteria that are explained in the previous section. The height of the tongue, which part of the tongue is raised the highest and lips rounding. The following diagram shows the positions of the English long vowels . (Jones, 2006 :Viiii)

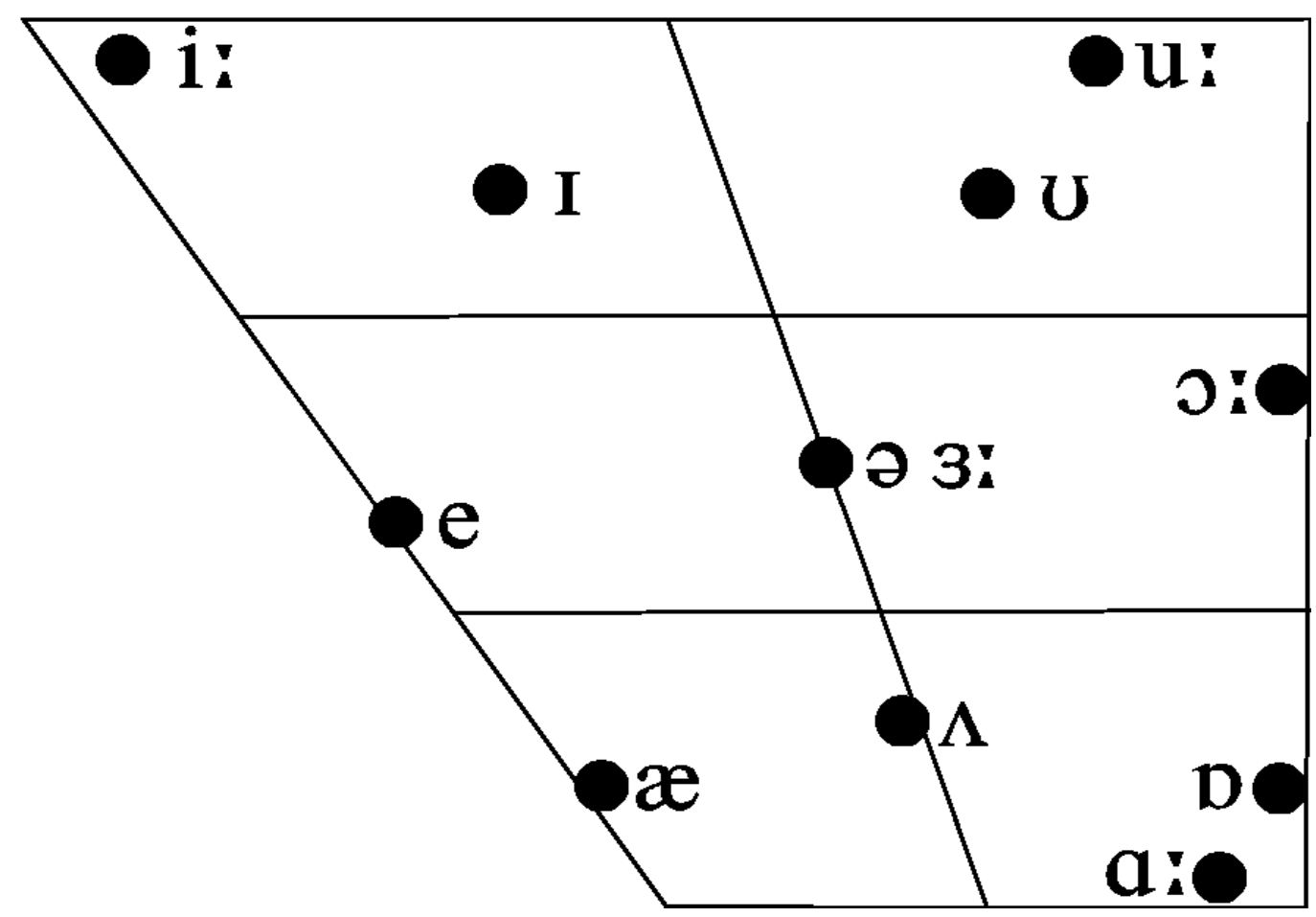

Figure(2):BBC English Pure Vowels

1- The vowel / I / , classified as short vowel, just above half-close position , front , and unrounded or spread.

2- The vowel /e / is short, between half-close and half-open position , front, and unrounded.

3- The vowel / æ / is short, just above the open position , front, and unrounded. 


\section{هبلة أبحاث هيسان، المبلد السابع عشر، العدد الرابع والثلاثون، كانون الأول، السنة 2021}

\section{https://doi.org/10.52834/jmr.v17i34.82}

4- The vowel / $\Lambda$ / is short, just below the half-open position, central , and unrounded.

5- The vowel / $\mathrm{p} /$ is short, between half-open and half-close, back, and rounded.

6- The vowel / $v /$ is short, just above half close, back, and rounded.

7- The vowel / $\partial$ / is short, between half-open and half-close, central, and rounded.

Long vowels are the following

$1-/ i: /$ is close, front, and unrounded.

$2-/$ a: / is open, back, and unrounded.

$3-/$ o: / is just below the half-close position, back , and rounded.

4-/u: / is just below the close position, back, and rounded.

$5-/ 3$ : / is between half-close and half-open, central, and unrounded .

\subsubsection{Diphthongs}

They are sounds that consist of a glide or movement from one single vowel to another single vowel. The first part of a diphthong is longer and stronger than the second part . English diphthongs include the following five diphthongs (Roach , $2009: 17-18)$. 


\section{DIPHTHONGS}

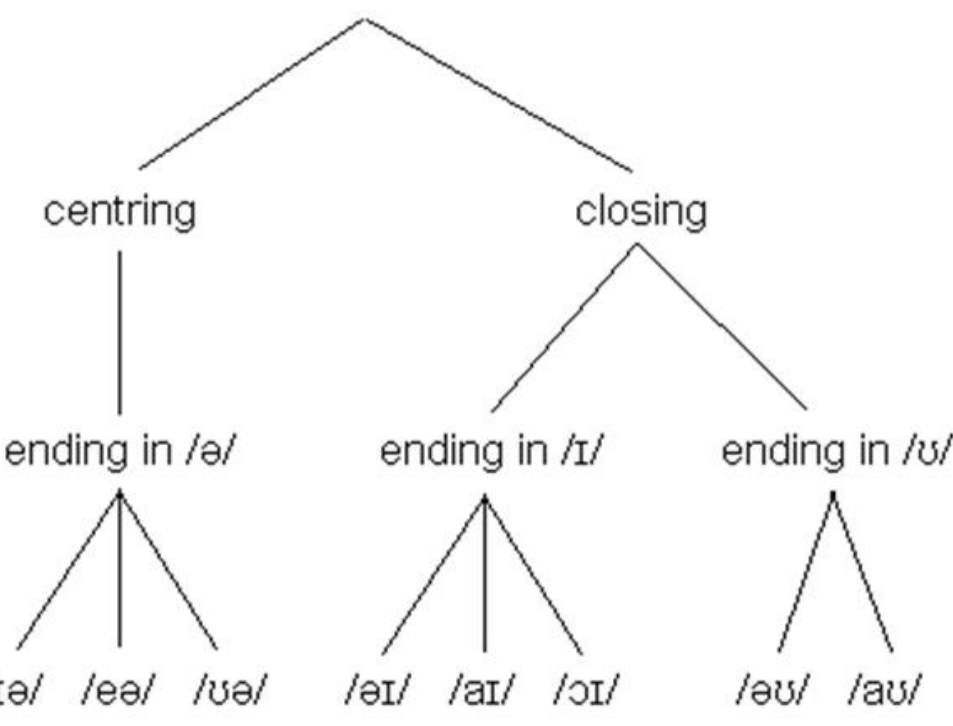

The eight English diphthongs

Redrawn by UKT from p.020, 090626

Figure (3): English diphthongs

$1-$ І гә / as in here / hıә/

2-/eə/ as in hair /heə/

$3-$ / ซə / as in poor / pซə/

$4-/ e_{I}$ / as in day / de I /

5-/ aI / as in my / maI/

6-/ गI / as in boy / bor /

$7-$ / əv / as in know / nəv /

8-/av / as in cow / kav / 


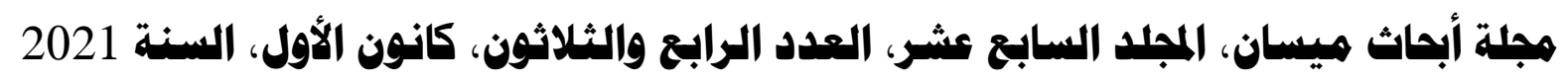

https://doi.org/10.52834/jmr.v17i34.82

Figure(4) : The positions of English Diphthongs

$1-/$ Іә /, the starting point of this vowel is usually higher than the position of the /I / monophthong in bit / bit /.

$2-/$ er / , this diphthong starts with a vowel sound that is more open than the of /e / get /get/.

3-/ ஏə / , the starting point of this vowel is higher than the position of the vowel in / $/$ put /pot/.

$4-/ \mathrm{e}_{\mathrm{I}} /$, the starting point of this vowel is the same as the / e/ of men /men/. 5-/ a / , this vowel begins with an open vowel which is between front and back ; it $/ \Lambda /$ is similar to of cut $/ k_{\Lambda} t /$.

$6-/$ or / , the beginning of this vowel is more open than /o: / of born / bo:n/. $7-/ \partial \mho /$, the starting point of this vowel is the same as / / / as in ago /əgəv/. $8^{-} /$av / , this vowel begins with a vowel that is similar to /a: / as in heart /ha:t/.

\subsubsection{Triphthongs}

Birjandi and Nodoushan (2005:63) define triphthongs as sounds that consist of a movement or glide from one vowel to another and then to a third. They are similar to diphthong but the difference is that triphthongs have an extra schwa at the 


\section{1}

https://doi.org/10.52834/jmr.v17i34.82

end of the diphthongs. They are five triphthongs.

$1-$ / avə/ as in power / pavə /

$2-$ / агә/ as in liar / lагə/

$3-/ \mathrm{e}_{\text {Iə/ }}$ as in layer / leıə/

$4-$ / огә/ as in loyal / bıә /

5-/ әуә / as in mower / mə๘ə /

The description of triphthongs

1-/ avə/, the starting point for this sound is similar to / a: / , continue to glide towards the back close position $/ \mho /$ and then to mid-central vowel $/ \mathrm{o} /$.

2-/ агә / , the starting point is similar to / a: /, goes on to move towards front close unrounded /I / then to / a / .

3- /егә/, the starting point is similar to / e / then to / I / then to / $/$ /.

4-/ әгә / , the beginning of this vowel is similar to / $\mathrm{\rho}:$ then to /I / and then to / ə I.

5-/ әуə /, the vowel begins with / / /, goes on to move towards close back rounded vowel / $v /$ then to /o / . (Roach , $2009: 19$ ) . 


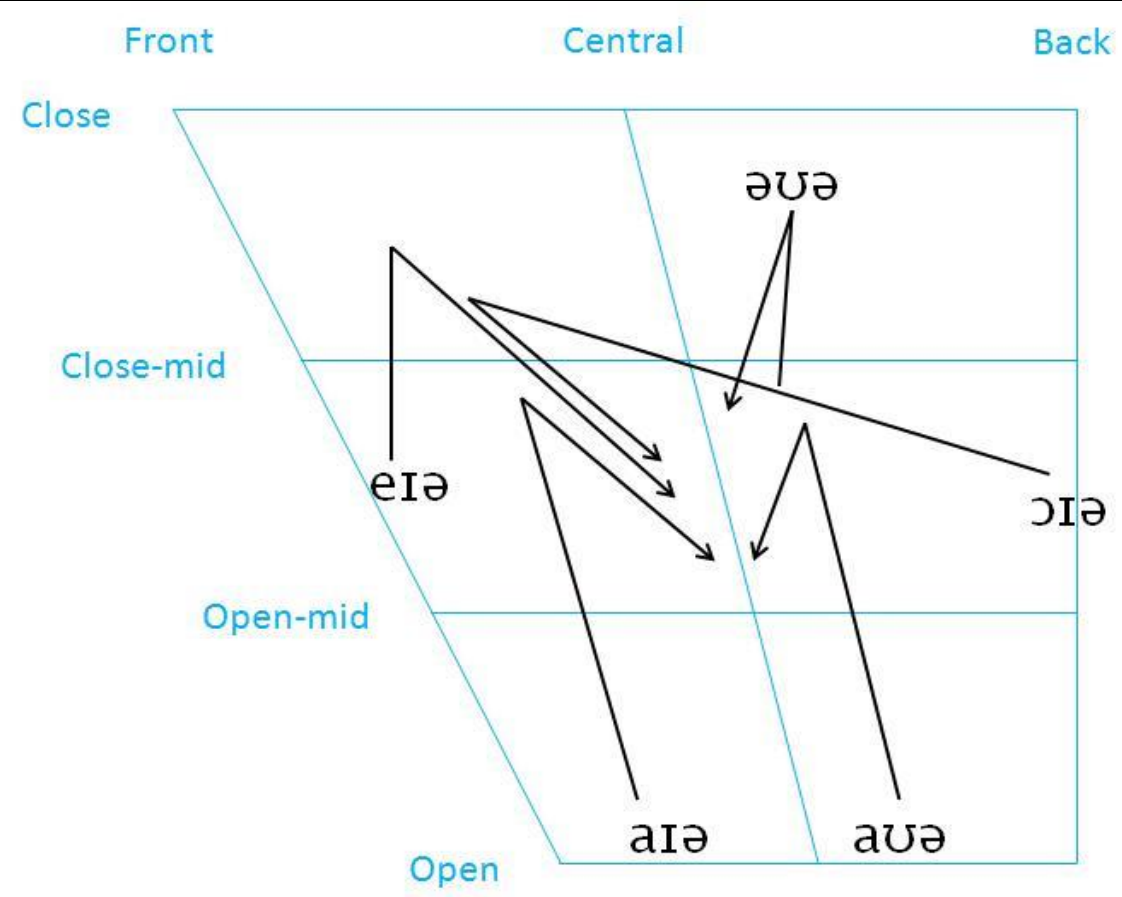

Figure(5) : The positions of English triphthongs

\section{The Experimental Part}

\subsection{Selection of stimuli}

The experiment was made in the form of a test consisting of BBC British English vowels (pure, diphthong and triphthong ) carried by 25 words. The words were written on paper so the speaker could see it before starting reading them. All the stimuli items were taken from Roach (2009:170-171). These words were given to the students to read individually and the students were told that their pronunciation would be recorded to be used in the research study. The students were instructed to speak clearly and carefully in order to be understood. They were asked to pronounce each word twice to later select the best recording for the analysis technique .

\subsection{The subjects}




\section{هجلة أبحاث هيسان، المبلد السابع عشر، العدد الرابع والثلاثون، كانون الأول، السنة 2021}

https://doi.org/10.52834/jmr.v17i34.82

The subjects were first stage students of the academic year (2016-2017) of the department of English, college of Education, university of Missan . They were all Imari Iraqi speakers because the study is limited for Imari speakers . All the subjects took part in the speech recording session. They were free of any speech anomalies or any neurologic or muscular condition that would be expected to affect their ability to produce speech. The number of the subjects that took part in the experiment is 20

\subsection{CD-Tape recording}

All the individual recordings were made by using a high quality MP3 Stereo recorder (Sony MP3 IC Recorder). The sony IC recorder has a Hi-speed USB direct $p c$ link. It also has a large storage memory, i.e. 50 hours maximum recording time.After conducting all the required recording sessions, the pronunciation of the words by each speaker saved in a particular file. The recorded words would be analyzed in order to show the duration, frequency, and pitch of all English vowel sounds .

\subsection{Praat}

It is " a computer program with which you can analyze, synthesize , manipulate speech, and create high-quality pictures for your articles and thesis " Boersma and Weenink $(2002: 45)$. It has two main pictures or windows.The first is " praat objects " . It is used for saving audio files and for recording sounds. The second window is the praat window which is used for drawings the waves. 


\section{هجلة أبحاث هيسان، المبلد السابع عشر، العدد الرابع والثلاثون، كانون الأول، السنة 2021}

https://doi.org/10.52834/jmr.v17i34.82

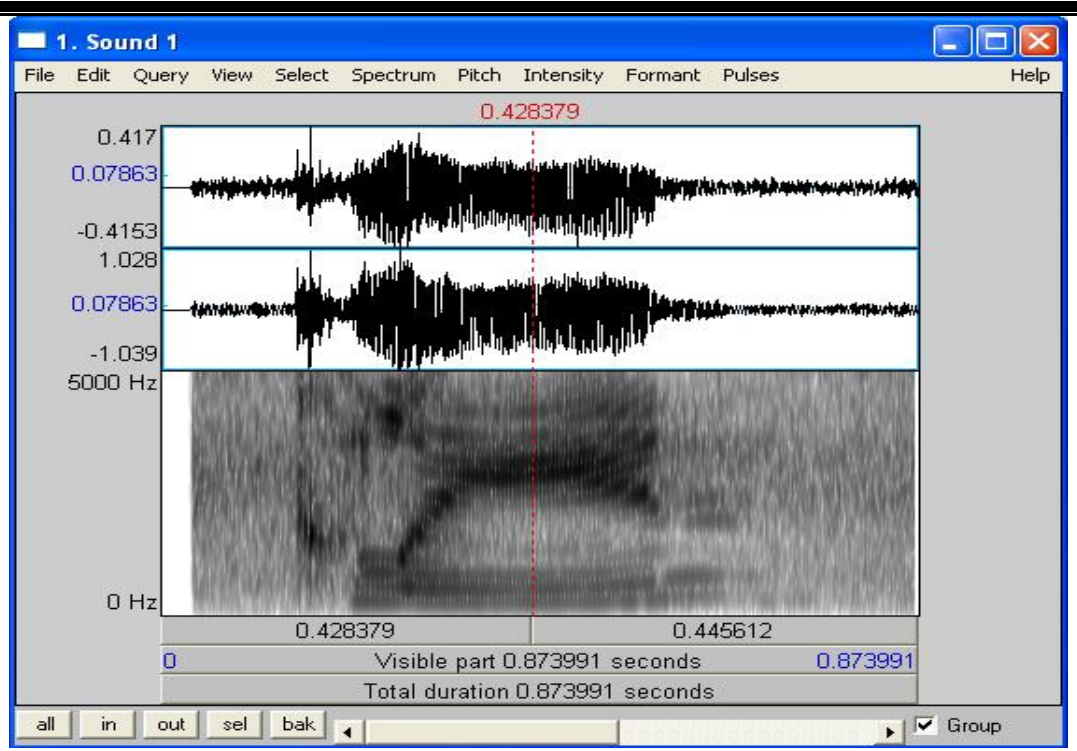

Figure (6) : praat picture

By using Praat, the researcher has measured the duration, the frequency, and the pitch of all the vowels pronounced by all the subjects . The researcher also has measured the duration, the frequency, and the pitch of all the vowels pronounced by the native speaker

Table (1) : The analysis of the sounds for the first student

\begin{tabular}{|c|c|c|c|}
\hline Sound & Duration & Fo in $(\mathrm{Hz})$ & Pitch \\
\hline$|\Lambda|$ & 0.105 & 221 & 76 \\
\hline$|\mathrm{p}|$ & 0.142 & 222 & 79 \\
\hline /e / & 0.194 & 220 & 76 \\
\hline$|æ|$ & 0.195 & 223 & 78 \\
\hline / I / & 0.138 & 226 & 75 \\
\hline$|v|$ & 0.158 & 220 & 78 \\
\hline$|0|$ & 0.105 & 207 & 77 \\
\hline / 3:/ & 0.186 & 211 & 75 \\
\hline / u:/ & 0.135 & 214 & 76 \\
\hline / $0: /$ & 0.159 & 215 & 75 \\
\hline
\end{tabular}


https://doi.org/10.52834/jmr.v17i34.82

\begin{tabular}{|c|c|c|c|}
\hline$/ a: /$ & 0.115 & 230 & 75 \\
\hline / i: / & 0.236 & 232 & 74 \\
\hline / e & 0.217 & 217 & 76 \\
\hline / $\mathrm{a}_{\mathrm{I}} /$ & 0.236 & 203 & 75 \\
\hline / OI / & 0.198 & 217 & 79 \\
\hline / $\partial \sigma /$ & 0.258 & 231 & 79 \\
\hline / av/ & 0.206 & 210 & 79 \\
\hline / гә/ & 0.257 & 215 & 79 \\
\hline / eə/ & 0.225 & 207 & 78 \\
\hline / ৩ə / & 0.209 & 213 & 76 \\
\hline /ёә/ & 0.268 & 214 & 73 \\
\hline / агә/ & 0.258 & 226 & 79 \\
\hline /ога/ & 0.300 & 207 & 97 \\
\hline /ə兀ə/ & 0.265 & 208 & 78 \\
\hline / ауə/ & 0.191 & 199 & 76 \\
\hline
\end{tabular}

Table (2) : The analysis of the sounds for the second student

\begin{tabular}{|c|c|c|c|}
\hline Sound & Duration & Fo in $(\mathrm{Hz})$ & Pitch \\
\hline$|\Lambda|$ & 0.349 & 203 & 74 \\
\hline$|\mathrm{p}|$ & 0.273 & 212 & 79 \\
\hline /e / & 0.238 & 209 & 79 \\
\hline$|æ|$ & 0.182 & 195 & 79 \\
\hline / I / & 0.160 & 188 & 79 \\
\hline$|v|$ & 0.238 & 219 & 80 \\
\hline$|\partial|$ & 0.034 & 201 & 79 \\
\hline / $3: /$ & 0.195 & 198 & 78 \\
\hline / u:/ & 0.258 & 220 & 81 \\
\hline / $0: /$ & 0.282 & 209 & 80 \\
\hline / $a: /$ & 0.224 & 220 & 81 \\
\hline
\end{tabular}


https://doi.org/10.52834/jmr.v17i34.82

\begin{tabular}{|c|c|c|c|}
\hline / i: / & 0.244 & 203 & 82 \\
\hline $\mid \mathrm{e}_{\mathrm{I}} /$ & 0.289 & 203 & 80 \\
\hline / $\mathrm{a}_{\mathrm{I}} /$ & 0.230 & 235 & 76 \\
\hline / or / & 0.273 & 201 & 80 \\
\hline / $\partial v /$ & 0.356 & 221 & 80 \\
\hline / av/ & 0.290 & 231 & 82 \\
\hline / гә/ & 0.244 & 222 & 80 \\
\hline / eə/ & 0.273 & 224 & 79 \\
\hline /৩ә / & 0.276 & 221 & 80 \\
\hline /егә/ & 0.194 & 249 & 78 \\
\hline / агә/ & 0.268 & 220 & 80 \\
\hline /огә/ & 0.360 & 227 & 81 \\
\hline /əஏə/ & 0.310 & 232 & 80 \\
\hline / ауə/ & 0.261 & 229 & 80 \\
\hline
\end{tabular}

Table (3) : The analysis of the sounds for the third student

\begin{tabular}{|c|c|c|c|}
\hline Sound & Duration & Fo in $(\mathrm{Hz})$ & Pitch \\
\hline$|\Lambda|$ & 0.191 & 277 & 75 \\
\hline $\mid \mathrm{p} /$ & 0.248 & 272 & 79 \\
\hline /e / & 0.188 & 258 & 80 \\
\hline$|æ|$ & 0.250 & 288 & 80 \\
\hline / I / & 0.180 & 277 & 79 \\
\hline$|v|$ & 0.284 & 280 & 79 \\
\hline$|\partial|$ & 0.103 & 218 & 79 \\
\hline / 3:/ & 0.160 & 261 & 82 \\
\hline / u:/ & 0.176 & 262 & 82 \\
\hline / $0: /$ & 0.250 & 248 & 81 \\
\hline / $a: /$ & 0.247 & 339 & 82 \\
\hline / i: / & 0.239 & 284 & 81 \\
\hline
\end{tabular}


https://doi.org/10.52834/jmr.v17i34.82

\begin{tabular}{|c|c|c|c|}
\hline$/ \mathrm{e}_{\mathrm{I}} /$ & 0.209 & 271 & 81 \\
\hline / $\mathrm{a}_{\mathrm{I}} /$ & 0.270 & 335 & 79 \\
\hline / оा / & 0.228 & 303 & 81 \\
\hline | $\partial \nu /$ & 0.281 & 278 & 81 \\
\hline | avo/ & 0.196 & 316 & 79 \\
\hline / гә/ & 0.276 & 286 & 79 \\
\hline / eə/ & 0.295 & 291 & 79 \\
\hline /vo / & 0.247 & 283 & 81 \\
\hline /егі/ & 0.301 & 261 & 80 \\
\hline / агә/ & 0.300 & 236 & 79 \\
\hline /огә/ & 0.290 & 311 & 81 \\
\hline /әуә/ & 0.380 & 250 & 80 \\
\hline | ауə/ & 0.341 & 230 & 79 \\
\hline
\end{tabular}

Table (4) : The analysis of the sounds for the fourth student

\begin{tabular}{|c|c|c|c|}
\hline Sound & Duration & Fo in $(\mathrm{Hz})$ & Pitch \\
\hline$|\Lambda|$ & 0.163 & 281 & 71 \\
\hline / $\mathrm{p} /$ & 0.237 & 279 & 71 \\
\hline /e / & 0.150 & 283 & 75 \\
\hline$|æ|$ & 0.149 & 272 & 73 \\
\hline / I / & 0.106 & 294 & 73 \\
\hline | $v$ | & 0.167 & 284 & 73 \\
\hline / o 1 & 0.073 & 299 & 76 \\
\hline / 3:/ & 0.200 & 270 & 77 \\
\hline / u:/ & 0.130 & 286 & 76 \\
\hline / o:/ & 0.184 & 281 & 75 \\
\hline / $a: /$ & 0.194 & 272 & 77 \\
\hline / i: / & 0.194 & 270 & 77 \\
\hline / $\mathrm{e}_{\mathrm{I}} /$ & 0.127 & 258 & 76 \\
\hline
\end{tabular}


https://doi.org/10.52834/jmr.v17i34.82

\begin{tabular}{|c|c|c|c|}
\hline / $\mathrm{a}_{\mathrm{I}} /$ & 0.254 & 272 & 75 \\
\hline / эI / & 0.280 & 262 & 75 \\
\hline $\mid \partial v /$ & 0.125 & 279 & 75 \\
\hline | av/ & 0.177 & 276 & 75 \\
\hline / гә/ & 0.208 & 269 & 75 \\
\hline / еə/ & 0.187 & 267 & 78 \\
\hline / vo / & 0.278 & 262 & 76 \\
\hline /егә/ & 0.310 & 274 & 76 \\
\hline / агә/ & 0.210 & 277 & 77 \\
\hline /огә/ & 0.295 & 268 & 76 \\
\hline /ə৩ə/ & 0.240 & 343 & 78 \\
\hline / ауə/ & 0.198 & 268 & 74 \\
\hline
\end{tabular}

Table (5) : The analysis of the sounds for the fifth student

\begin{tabular}{|c|c|c|c|}
\hline Sound & Duration & Fo in $(\mathrm{Hz})$ & Pitch \\
\hline$|\Lambda|$ & 0.233 & 285 & 77 \\
\hline$/ \mathrm{p} /$ & 0.144 & 278 & 77 \\
\hline /e / & 0.099 & 290 & 80 \\
\hline$|æ|$ & 0.175 & 256 & 78 \\
\hline / I / & 0.093 & 273 & 78 \\
\hline$|v|$ & 0.188 & 270 & 76 \\
\hline $10 \mid$ & 0.153 & 249 & 73 \\
\hline / 3:/ & 0.181 & 262 & 77 \\
\hline / u:/ & 0.219 & 271 & 76 \\
\hline / o:/ & 0.204 & 277 & 77 \\
\hline $\mid a: /$ & 0.195 & 270 & 79 \\
\hline / i: / & 0.231 & 270 & 78 \\
\hline / $\mathrm{e}_{\mathrm{I}} /$ & 0.159 & 258 & 76 \\
\hline / $a_{I} /$ & 0.183 & 258 & 78 \\
\hline
\end{tabular}


https://doi.org/10.52834/jmr.v17i34.82

\begin{tabular}{|c|c|c|c|}
\hline / OI / & 0.225 & 266 & 75 \\
\hline | әे/ & 0.206 & 274 & 74 \\
\hline$|a v|$ & 0.193 & 271 & 76 \\
\hline / гә/ & 0.228 & 259 & 78 \\
\hline / eə/ & 0.210 & 255 & 76 \\
\hline /৩ә / & 0.196 & 274 & 75 \\
\hline /егә/ & 0.310 & 259 & 76 \\
\hline / агә/ & 0.390 & 258 & 75 \\
\hline /ог/ & 0.311 & 261 & 78 \\
\hline /әуә/ & 0.390 & 311 & 76 \\
\hline | ауə/ & 0.340 & 315 & 73 \\
\hline
\end{tabular}

Table (6) : The analysis of the sounds for student number six

\begin{tabular}{|c|c|c|c|}
\hline Sound & Duration & Fo in $(\mathrm{Hz})$ & Pitch \\
\hline$|\Lambda|$ & 0.257 & 245 & 69 \\
\hline $\mid \mathrm{p} /$ & 0.227 & 242 & 75 \\
\hline /e / & 0.124 & 233 & 78 \\
\hline$|æ|$ & 0.129 & 234 & 79 \\
\hline / I / & 0.160 & 230 & 77 \\
\hline$|v|$ & 0.165 & 249 & 76 \\
\hline $10 \mid$ & 0.092 & 222 & 74 \\
\hline / 3:/ & 0.161 & 233 & 79 \\
\hline / u:/ & 0.091 & 248 & 81 \\
\hline / o:/ & 0.131 & 240 & 81 \\
\hline $\mid a: /$ & 0.121 & 233 & 81 \\
\hline /i: / & 0.148 & 236 & 80 \\
\hline $\mid \mathrm{e}_{\mathrm{I}} /$ & 0.172 & 247 & 82 \\
\hline / $a_{I} /$ & 0.164 & 237 & 80 \\
\hline
\end{tabular}


https://doi.org/10.52834/jmr.v17i34.82

\begin{tabular}{|c|c|c|c|}
\hline / or / & 0.188 & 257 & 82 \\
\hline | $\partial \nu /$ & 0.183 & 251 & 81 \\
\hline $\mid a v /$ & 0.149 & 257 & 82 \\
\hline / гә/ & 0.138 & 243 & 81 \\
\hline / eə/ & 0.119 & 242 & 81 \\
\hline / ৩ə / & 0.206 & 225 & 77 \\
\hline /егіә/ & 0.431 & 225 & 77 \\
\hline / агә/ & 0.368 & 230 & 75 \\
\hline /огә/ & 0.430 & 243 & 76 \\
\hline /әЈә/ & 0.364 & 323 & 77 \\
\hline / ауə/ & 0.269 & 181 & 77 \\
\hline
\end{tabular}

Table (7) : The analysis of the sounds for student number seven

\begin{tabular}{|c|c|c|c|}
\hline Sound & Duration & Fo in( $\mathrm{Hz})$ & Pitch \\
\hline$/ \Lambda /$ & 0.159 & 242 & 7479 \\
\hline / p / & 0.175 & 261 & 81 \\
\hline /e / & 0.129 & 268 & 80 \\
\hline$|æ|$ & 0.274 & 235 & 80 \\
\hline / I / & 0.137 & 261 & 82 \\
\hline | v | & 0.211 & 261 & 81 \\
\hline$|0|$ & 0.086 & 238 & 77 \\
\hline / 3:/ & 0.220 & 254 & 80 \\
\hline / u:/ & 0.109 & 277 & 83 \\
\hline / $0: /$ & 0.218 & 258 & 82 \\
\hline$|a:|$ & 0.166 & 246 & 79 \\
\hline / i: / & 0.282 & 246 & 80 \\
\hline / $\mathrm{e}_{\mathrm{I}}$ / & 0.205 & 255 & 79 \\
\hline / $a_{I} /$ & 0.209 & 249 & 81 \\
\hline / оा / & 0.249 & 241 & 78 \\
\hline
\end{tabular}


https://doi.org/10.52834/jmr.v17i34.82

\begin{tabular}{|c|c|c|c|}
\hline$|\partial v|$ & 0.260 & 261 & 81 \\
\hline $\mid a v /$ & 0.247 & 244 & 82 \\
\hline / гә/ & 0.264 & 258 & 80 \\
\hline / еə/ & 0.248 & 266 & 83 \\
\hline / ๘ә / & 0.200 & 249 & 78 \\
\hline /еІә/ & 0.268 & 250 & 79 \\
\hline / агә/ & 0.311 & 243 & 78 \\
\hline /огә/ & 0.400 & 234 & 77 \\
\hline /әОә/ & 0.346 & 244 & 79 \\
\hline / avə/ & 0.433 & 230 & 76 \\
\hline
\end{tabular}

Table (8) : The analysis of the sounds for student number eight

\begin{tabular}{|c|c|c|c|}
\hline Sound & Duration & Fo in $(\mathrm{Hz})$ & Pitch \\
\hline$|\Lambda|$ & 0.104 & 151 & 75 \\
\hline$/ \mathrm{p} /$ & 0.101 & 141 & 75 \\
\hline /e / & 0.068 & 146 & 73 \\
\hline$|æ|$ & 0.120 & 144 & 74 \\
\hline / I / & 0.076 & 147 & 74 \\
\hline$|v|$ & 0.100 & 161 & 75 \\
\hline $10 \mid$ & 0.041 & 141 & 69 \\
\hline / 3:/ & 0.111 & 143 & 77 \\
\hline / u:/ & 0.073 & 139 & 74 \\
\hline / $0: /$ & 0.134 & 139 & 74 \\
\hline$/ a: /$ & 0.135 & 147 & 76 \\
\hline / i: / & 0.128 & 143 & 76 \\
\hline$/ \mathrm{e}_{\mathrm{I}} /$ & 0.169 & 139 & 72 \\
\hline / $\mathrm{a}_{\mathrm{I}} /$ & 0.176 & 138 & 74 \\
\hline / गा / & 0.130 & 139 & 74 \\
\hline / әv/ & 0.124 & 160 & 76 \\
\hline
\end{tabular}


https://doi.org/10.52834/jmr.v17i34.82

\begin{tabular}{|c|c|c|c|}
\hline$|a v|$ & 0.110 & 146 & 76 \\
\hline / гә/ & 0.166 & 143 & 75 \\
\hline / еә/ & 0.104 & 146 & 76 \\
\hline |๘ə / & 0.100 & 143 & 75 \\
\hline /еІә/ & 0.168 & 141 & 77 \\
\hline / агә/ & 0.078 & 163 & 75 \\
\hline / эг/ & 0.142 & 145 & 75 \\
\hline /әбә/ & 0.122 & 145 & 76 \\
\hline | ауə/ & 0.123 & 159 & 74 \\
\hline
\end{tabular}

Table (9) : The analysis of the sounds for student number nine

\begin{tabular}{|c|c|c|c|}
\hline Sound & Duration & Fo in $(\mathrm{Hz})$ & Pitch \\
\hline$|\Lambda|$ & 0.075 & 147 & 75 \\
\hline $\mid \mathrm{p} /$ & 0.128 & 139 & 75 \\
\hline /e / & 0.082 & 145 & 75 \\
\hline$|æ|$ & 0.115 & 135 & 77 \\
\hline / I / & 0.078 & 139 & 76 \\
\hline$|v|$ & 0.144 & 141 & 76 \\
\hline$|0|$ & 0.068 & 142 & 67 \\
\hline / 3:/ & 0.143 & 141 & 78 \\
\hline / u:/ & 0.156 & 149 & 77 \\
\hline / $0: /$ & 0.166 & 164 & 76 \\
\hline $\mid a: /$ & 0.126 & 140 & 79 \\
\hline / i: / & 0.157 & 138 & 75 \\
\hline$/ \mathrm{e}_{\mathrm{I}} /$ & 0.109 & 150 & 74 \\
\hline / $a_{I} /$ & 0.199 & 141 & 66 \\
\hline / оा / & 0.140 & 145 & 69 \\
\hline | $\partial \theta /$ & 0.092 & 146 & 75 \\
\hline | av/ & 0.068 & 148 & 75 \\
\hline
\end{tabular}


https://doi.org/10.52834/jmr.v17i34.82

\begin{tabular}{|c|c|c|c|}
\hline / гә/ & 0.211 & 162 & 72 \\
\hline / еə/ & 0.145 & 139 & 66 \\
\hline /৩o / & 0.064 & 141 & 77 \\
\hline /егә/ & 0.139 & 144 & 75 \\
\hline / атә/ & 0.132 & 135 & 72 \\
\hline /ога/ & 0.140 & 139 & 70 \\
\hline |әЈә/ & 0.200 & 140 & 75 \\
\hline / ауə/ & 0.122 & 132 & 74 \\
\hline
\end{tabular}

Table (10) : The analysis of the sounds for student number ten

\begin{tabular}{|c|c|c|c|}
\hline Sound & Duration & $\mathrm{Fo}(\mathrm{Hz})$ & Pitch \\
\hline$|\Lambda|$ & 0.110 & 128 & 75 \\
\hline / p / & 0.135 & 120 & 75 \\
\hline /e / & 0.101 & 118 & 75 \\
\hline$|æ|$ & 0.176 & 121 & 76 \\
\hline / I / & 0.089 & 114 & 76 \\
\hline$|v|$ & 0.120 & 120 & 78 \\
\hline $10 \mid$ & 0.132 & 132 & 76 \\
\hline / 3:/ & 0.141 & 129 & 76 \\
\hline / u:/ & 0.164 & 116 & 75 \\
\hline / $0: /$ & 0.109 & 130 & 75 \\
\hline / $a: /$ & 0.132 & 118 & 73 \\
\hline / i: / & 0.121 & 127 & 74 \\
\hline / e & 0.123 & 121 & 75 \\
\hline / $\mathrm{a}_{\mathrm{I}} /$ & 0.130 & 119 & 73 \\
\hline / ог / & 0.103 & 133 & 75 \\
\hline | $\partial v \mid$ & 0.144 & 134 & 74 \\
\hline | av/ & 0.108 & 124 & 77 \\
\hline
\end{tabular}


https://doi.org/10.52834/jmr.v17i34.82

\begin{tabular}{|c|c|c|c|}
\hline / гә/ & 0.141 & 112 & 76 \\
\hline / еə/ & 0.156 & 117 & 72 \\
\hline /ण0 / & 0.164 & 108 & 75 \\
\hline /егә/ & 0.111 & 132 & 76 \\
\hline / агә/ & 0.123 & 138 & 75 \\
\hline /әгә/ & 0.090 & 139 & 74 \\
\hline /əЈə/ & 0.116 & 113 & 74 \\
\hline / ауə/ & 0.143 & 135 & 75 \\
\hline
\end{tabular}

Table (11) : The analysis of the sounds for student number eleven

\begin{tabular}{|c|c|c|c|}
\hline Sound & Duration & $\mathrm{FO}$ in $(\mathrm{Hz})$ & Pitch \\
\hline$|\Lambda|$ & 0.089 & 143 & 75 \\
\hline / p / & 0.128 & 139 & 75 \\
\hline /e / & 0.064 & 144 & 75 \\
\hline |æ / & 0.120 & 137 & 76 \\
\hline / I / & 0.146 & 140 & 76 \\
\hline$|v|$ & 0.118 & 143 & 76 \\
\hline $10 \mid$ & 0.061 & 138 & 76 \\
\hline / 3:/ & 0.130 & 123 & 75 \\
\hline / u:/ & 0.128 & 137 & 75 \\
\hline / o:/ & 0.116 & 149 & 72 \\
\hline$/ a: /$ & 0.140 & 134 & 74 \\
\hline / i: / & 0.118 & 126 & 73 \\
\hline / e & 0.120 & 132 & 72 \\
\hline / $a_{I} /$ & 0.090 & 131 & 72 \\
\hline / эг / & 0.140 & 145 & 74 \\
\hline | $\partial v /$ & 0.133 & 139 & 76 \\
\hline | av/ & 0.123 & 143 & 76 \\
\hline / гә/ & 0.125 & 132 & 75 \\
\hline
\end{tabular}


https://doi.org/10.52834/jmr.v17i34.82

\begin{tabular}{|c|c|c|c|}
\hline / еə/ & 0.054 & 129 & 74 \\
\hline /৩ә / & 0.132 & 137 & 77 \\
\hline /еІә/ & 0.209 & 143 & 75 \\
\hline / агә/ & 0.343 & 132 & 78 \\
\hline /ога/ & 0.423 & 144 & 78 \\
\hline /ә0ә/ & 0.424 & 140 & 76 \\
\hline / аvə/ & 0.587 & 134 & 75 \\
\hline
\end{tabular}

Table (12) : The analysis of the sounds for student number twelve

\begin{tabular}{|c|c|c|c|}
\hline Sound & Duration & $\mathrm{FO}$ in $(\mathrm{Hz})$ & Pitch \\
\hline$|\Lambda|$ & 0.110 & 128 & 76 \\
\hline$/ \mathrm{p} /$ & 0.135 & 120 & 75 \\
\hline /e / & 0.155 & 118 & 75 \\
\hline$|æ|$ & 0.176 & 121 & 76 \\
\hline / I / & 0.085 & 114 & 75 \\
\hline$|v|$ & 0.109 & 129 & 77 \\
\hline $10 \mid$ & 0.154 & 130 & 73 \\
\hline / $3: /$ & 0.166 & 112 & 73 \\
\hline / u:/ & 0.123 & 108 & 74 \\
\hline / $0: /$ & 0.154 & 105 & 72 \\
\hline$/ a: /$ & 0.163 & 122 & 76 \\
\hline / i: / & 0.134 & 121 & 76 \\
\hline$/ \mathrm{e}_{\mathrm{I}} /$ & 0.105 & 116 & 76 \\
\hline / $\mathrm{a}_{\mathrm{I}}$ / & 0.122 & 102 & 74 \\
\hline / गI / & 0.166 & 124 & 75 \\
\hline | $20 /$ & 0.133 & 117 & 75 \\
\hline$|a v|$ & 0.143 & 104 & 76 \\
\hline / гә/ & 0.111 & 124 & 72 \\
\hline / es/ & 0.119 & 127 & 73 \\
\hline
\end{tabular}


https://doi.org/10.52834/jmr.v17i34.82

\begin{tabular}{|c|c|c|c|}
\hline /๘ә/ & 0.165 & 113 & 74 \\
\hline /егә/ & 0.145 & 106 & 75 \\
\hline / агә/ & 0.124 & 130 & 76 \\
\hline /ог/ & 0.144 & 129 & 76 \\
\hline /әуә/ & 0.134 & 112 & 75 \\
\hline / ауә/ & 0.089 & 107 & 75 \\
\hline
\end{tabular}

Table (13) : The analysis of the sounds for student number thirteen

\begin{tabular}{|c|c|c|c|}
\hline Sound & Duration & $\mathrm{FO}$ in $(\mathrm{Hz})$ & Pitch \\
\hline$|\Lambda|$ & 0.104 & 135 & 75 \\
\hline $\mid \mathrm{p} /$ & 0.073 & 136 & 75 \\
\hline /e / & 0.110 & 133 & 76 \\
\hline$|æ|$ & 0.123 & 143 & 76 \\
\hline / I / & 0.121 & 140 & 77 \\
\hline$|v|$ & 0.089 & 141 & 67 \\
\hline 101 & 0.134 & 139 & 75 \\
\hline / 3:/ & 0.105 & 132 & 75 \\
\hline / u:/ & 0.111 & 127 & 74 \\
\hline / o:/ & 0.076 & 132 & 73 \\
\hline$/ a: /$ & 0.108 & 121 & 72 \\
\hline / i: / & 0.104 & 130 & 77 \\
\hline$/ \mathrm{e}_{\mathrm{I}} /$ & 0.133 & 132 & 76 \\
\hline / $\mathrm{a}_{\mathrm{I}}$ / & 0.113 & 125 & 76 \\
\hline / oI / & 0.125 & 109 & 75 \\
\hline / əo/ & 0.102 & 117 & 75 \\
\hline | av/ & 0.145 & 143 & 75 \\
\hline / Іә/ & 0.143 & 140 & 75 \\
\hline / еə/ & 0.123 & 143 & 74 \\
\hline /\%ə / & 0.111 & 125 & 72 \\
\hline
\end{tabular}


https://doi.org/10.52834/jmr.v17i34.82

\begin{tabular}{|c|l|l|l|}
\hline /егә/ & 0.107 & 137 & 73 \\
\hline / агә/ & 0.123 & 146 & 76 \\
\hline /әә/ & 0.120 & 143 & 77 \\
\hline /әбә/ & 0.132 & 132 & 75 \\
\hline / ауә/ & 0.121 & 133 & 75 \\
\hline
\end{tabular}

Table (14) : The analysis of the sounds for student number fourteen

\begin{tabular}{|c|c|c|c|}
\hline Sound & Duration & $\mathrm{FO}$ in $(\mathrm{Hz})$ & Pitch \\
\hline$|\Lambda|$ & 0.102 & 143 & 77 \\
\hline$/ \mathrm{p} /$ & 0.132 & 140 & 77 \\
\hline /e / & 0.107 & 132 & 76 \\
\hline$|æ|$ & 0.142 & 130 & 74 \\
\hline / I / & 0.124 & 127 & 77 \\
\hline$|v|$ & 0.102 & 109 & 75 \\
\hline $10 \mid$ & 0.122 & 117 & 75 \\
\hline / 3:/ & 0.109 & 118 & 75 \\
\hline / u:/ & 0.103 & 123 & 75 \\
\hline / $0: /$ & 0.132 & 132 & 75 \\
\hline$/ a: /$ & 0.133 & 124 & 73 \\
\hline / i: / & 0.124 & 145 & 73 \\
\hline / e & 0.145 & 120 & 76 \\
\hline / $\mathrm{a}_{\mathrm{I}}$ & 0.144 & 121 & 72 \\
\hline / गІ / & 0.140 & 132 & 75 \\
\hline | $\partial v /$ & 0.134 & 133 & 77 \\
\hline | avo/ & 0.122 & 134 & 77 \\
\hline / Іә/ & 0.105 & 102 & 75 \\
\hline / eə/ & 0.122 & 105 & 75 \\
\hline / ৩ə / & 0.114 & 118 & 74 \\
\hline /енә/ & 0.145 & 122 & 73 \\
\hline
\end{tabular}


https://doi.org/10.52834/jmr.v17i34.82

\begin{tabular}{|c|c|c|c|}
\hline / агә/ & 0.133 & 128 & 74 \\
\hline /оә/ & 0.089 & 134 & 75 \\
\hline /әуә/ & 0.109 & 140 & 75 \\
\hline / ауә/ & 0.143 & 139 & 75 \\
\hline
\end{tabular}

Table (15) : The analysis of the sounds for student number fifteen

\begin{tabular}{|c|c|c|c|}
\hline Sound & Duration & $\mathrm{FO}$ in $(\mathrm{Hz})$ & Pitch \\
\hline$|\Lambda|$ & 0.109 & 123 & 73 \\
\hline$/ p /$ & 0.111 & 143 & 73 \\
\hline /e / & 0.132 & 144 & 74 \\
\hline$|æ|$ & 0.126 & 109 & 73 \\
\hline / I / & 0.124 & 127 & 68 \\
\hline$|v|$ & 0.133 & 135 & 75 \\
\hline | o | & 0.135 & 120 & 75 \\
\hline / 3:/ & 0.176 & 132 & 75 \\
\hline / u:/ & 0.109 & 122 & 75 \\
\hline / o:/ & 0.165 & 119 & 75 \\
\hline$/ a: /$ & 0.113 & 123 & 75 \\
\hline / i: / & 0.145 & 114 & 75 \\
\hline / e & 0.144 & 120 & 77 \\
\hline / $\mathrm{a}_{\mathrm{I}} /$ & 0.154 & 130 & 76 \\
\hline / or / & 0.109 & 134 & 76 \\
\hline | əठ/ & 0.108 & 137 & 77 \\
\hline / av/ & 0.104 & 117 & 77 \\
\hline / тә/ & 0.112 & 123 & 77 \\
\hline / еə/ & 0.121 & 132 & 73 \\
\hline /və / & 0.132 & 144 & 74 \\
\hline /еІа/ & 0.142 & 145 & 72 \\
\hline / агә/ & 0.143 & 122 & 77 \\
\hline
\end{tabular}


https://doi.org/10.52834/jmr.v17i34.82

\begin{tabular}{|l|l|l|l|}
\hline /ог/ & 0.114 & 143 & 75 \\
\hline /әуә/ & 0.080 & 146 & 76 \\
\hline / ауә/ & 0.089 & 109 & 76 \\
\hline
\end{tabular}

Table (16) : The analysis of the sounds for student number sixteen

\begin{tabular}{|c|c|c|c|}
\hline Sound & Duration & $\mathrm{FO}$ in $(\mathrm{Hz})$ & Pitch \\
\hline$|\Lambda|$ & 0.114 & 143 & 75 \\
\hline$/ \mathrm{p} /$ & 0.128 & 280 & 79 \\
\hline /e / & 0.064 & 218 & 79 \\
\hline$|æ|$ & 0.120 & 261 & 82 \\
\hline / I / & 0.146 & 262 & 82 \\
\hline$|v|$ & 0.121 & 248 & 81 \\
\hline$|0|$ & 0.132 & 339 & 82 \\
\hline / $3: /$ & 0.142 & 284 & 81 \\
\hline / u:/ & 0.143 & 271 & 81 \\
\hline / $0: /$ & 0.114 & 335 & 79 \\
\hline$/ a: /$ & 0.080 & 303 & 81 \\
\hline / i: / & 0.089 & 278 & 81 \\
\hline$/ \mathrm{e}_{\mathrm{I}} /$ & 0.220 & 316 & 79 \\
\hline / $\mathrm{a}_{\mathrm{I}} /$ & 0.109 & 286 & 79 \\
\hline | गा / & 0.218 & 291 & 79 \\
\hline | $\partial \sigma \mid$ & 0.166 & 283 & 81 \\
\hline $\mid \mathrm{av} /$ & 0.282 & 261 & 80 \\
\hline / гә/ & 0.205 & 236 & 79 \\
\hline / еə/ & 0.209 & 311 & 81 \\
\hline / טo / & 0.249 & 250 & 80 \\
\hline /ёә/ & 0.260 & 230 & 79 \\
\hline / агә/ & 0.166 & 143 & 75 \\
\hline /ог/ & 0.130 & 139 & 74 \\
\hline
\end{tabular}


https://doi.org/10.52834/jmr.v17i34.82

\begin{tabular}{|l|l|l|l|}
\hline /əoə/ & 0.124 & 160 & 76 \\
\hline / avə/ & 0.110 & 146 & 76 \\
\hline
\end{tabular}

Table (17) : The analysis of the sounds for student number seventeen

\begin{tabular}{|c|c|c|c|}
\hline Sound & Duration & $\mathrm{FO}$ in $(\mathrm{Hz})$ & Pitch \\
\hline$|\Lambda|$ & 0.034 & 132 & 75 \\
\hline$|\mathrm{p}|$ & 0.195 & 117 & 75 \\
\hline /e / & 0.258 & 104 & 76 \\
\hline$|æ|$ & 0.282 & 124 & 72 \\
\hline / I / & 0.224 & 127 & 73 \\
\hline$|v|$ & 0.244 & 113 & 74 \\
\hline$|\partial|$ & 0.289 & 106 & 75 \\
\hline / 3:/ & 0.230 & 130 & 76 \\
\hline / u:/ & 0.273 & 129 & 76 \\
\hline / $0: /$ & 0.356 & 112 & 75 \\
\hline $\mid a: /$ & 0.290 & 107 & 75 \\
\hline / i: / & 0.244 & 187 & 77 \\
\hline $\mid \mathrm{e}_{\mathrm{I}} /$ & 0.273 & 189 & 76 \\
\hline / $\mathrm{a}_{\mathrm{I}} /$ & 0.276 & 240 & 75 \\
\hline / ग1 / & 0.194 & 217 & 78 \\
\hline | $\partial v /$ & 0.180 & 277 & 79 \\
\hline / av/ & 0.284 & 280 & 79 \\
\hline / гә/ & 0.103 & 218 & 79 \\
\hline / еə/ & 0.160 & 261 & 82 \\
\hline / ৩ə / & 0.176 & 262 & 82 \\
\hline /еІә/ & 0.250 & 248 & 81 \\
\hline / агә/ & 0.248 & 272 & 79 \\
\hline /ога/ & 0.188 & 258 & 80 \\
\hline /ә৩ә/ & 0.250 & 288 & 80 \\
\hline
\end{tabular}


https://doi.org/10.52834/jmr.v17i34.82

| avə/

0.173

180

75

Table (18) : The analysis of the sounds for student number eighteen

\begin{tabular}{|c|c|c|c|}
\hline Sound & Duration & $\mathrm{FO}$ in $(\mathrm{Hz})$ & Pitch \\
\hline$|\Lambda|$ & 0.112 & 227 & 75 \\
\hline$/ \mathrm{p} /$ & 0.122 & 229 & 75 \\
\hline /e / & 0.132 & 222 & 76 \\
\hline$|æ|$ & 0.143 & 120 & 77 \\
\hline / I / & 0.122 & 143 & 76 \\
\hline$|v|$ & 0.136 & 141 & 76 \\
\hline $\mid$ o | & 0.089 & 203 & 68 \\
\hline / 3:/ & 0.111 & 109 & 80 \\
\hline / u:/ & 0.109 & 144 & 80 \\
\hline / o:/ & 0.134 & 143 & 77 \\
\hline$/ a: /$ & 0.154 & 123 & 76 \\
\hline / i: / & 0.142 & 163 & 75 \\
\hline$/ \mathrm{e}_{\mathrm{I}} /$ & 0.123 & 133 & 75 \\
\hline$/ \mathrm{a}_{\mathrm{I}} /$ & 0.111 & 201 & 73 \\
\hline / or / & 0.109 & 145 & 74 \\
\hline / $20 /$ & 0.127 & 134 & 74 \\
\hline $\mid a v /$ & 0.148 & 143 & 72 \\
\hline / Іә/ & 0.107 & 115 & 73 \\
\hline / еә/ & 0.210 & 106 & 75 \\
\hline /৩ə / & 0.180 & 105 & 76 \\
\hline /ёг/ & 0.136 & 109 & 77 \\
\hline / атә/ & 0.154 & 150 & 77 \\
\hline /วга/ & 0.149 & 132 & 75 \\
\hline /ə0ə/ & 0.141 & 129 & 75 \\
\hline / avə/ & 0.202 & 130 & 75 \\
\hline
\end{tabular}


https://doi.org/10.52834/jmr.v17i34.82

Table (19) : The analysis of the sounds for student number nineteen

\begin{tabular}{|c|c|c|c|}
\hline Sound & Duration & $\mathrm{FO}$ in $(\mathrm{Hz})$ & Pitch \\
\hline$|\Lambda|$ & 113 & 210 & 75 \\
\hline$/ \mathrm{p} /$ & 0.139 & 170 & 75 \\
\hline /e / & 0.120 & 261 & 82 \\
\hline$|æ|$ & 0.146 & 262 & 82 \\
\hline / I / & 0.121 & 248 & 81 \\
\hline$|v|$ & 0.132 & 339 & 82 \\
\hline | o | & 0.142 & 284 & 81 \\
\hline / $3: /$ & 0.143 & 271 & 81 \\
\hline / u:/ & 0.114 & 335 & 79 \\
\hline / $0: /$ & 0.080 & 303 & 81 \\
\hline $\mid a: /$ & 0.089 & 278 & 81 \\
\hline / i: / & 0.220 & 316 & 79 \\
\hline$/ \mathrm{e}_{\mathrm{I}} /$ & 0.109 & 286 & 79 \\
\hline / $\mathrm{a}_{\mathrm{I}} /$ & 0.120 & 124 & 75 \\
\hline / ог / & 0.108 & 137 & 77 \\
\hline | əo/ & 0.104 & 117 & 77 \\
\hline | av/ & 0.112 & 123 & 77 \\
\hline / гә/ & 0.121 & 132 & 73 \\
\hline / eə/ & 0.132 & 144 & 74 \\
\hline /vo / & 0.142 & 145 & 72 \\
\hline /ена/ & 0.143 & 122 & 77 \\
\hline / агә/ & 0.114 & 143 & 75 \\
\hline /ог/ & 0.080 & 146 & 76 \\
\hline /ə0ə/ & 0.089 & 109 & 76 \\
\hline / avə/ & 0.143 & 143 & 77 \\
\hline
\end{tabular}


https://doi.org/10.52834/jmr.v17i34.82

Table (20) : The analysis of the sounds for student number twenty

\begin{tabular}{|c|c|c|c|}
\hline Sound & Duration & $\mathrm{FO}$ in $(\mathrm{Hz})$ & Pitch \\
\hline$|\Lambda|$ & 0.139 & 122 & 76 \\
\hline $\mid \mathrm{p} /$ & 0.116 & 149 & 72 \\
\hline /e / & 0.140 & 134 & 74 \\
\hline |æ / & 0.118 & 126 & 73 \\
\hline / I / & 0.120 & 132 & 72 \\
\hline$|v|$ & 0.090 & 131 & 72 \\
\hline | o | & 0.140 & 145 & 74 \\
\hline / 3:/ & 0.133 & 139 & 76 \\
\hline / u:/ & 0.123 & 143 & 76 \\
\hline / $0: /$ & 0.125 & 132 & 75 \\
\hline$|a:|$ & 0.054 & 129 & 74 \\
\hline / i: / & 0.132 & 137 & 77 \\
\hline / $\mathrm{e}_{\mathrm{I}} /$ & 0.209 & 143 & 75 \\
\hline / $\mathrm{a}_{\mathrm{I}} /$ & 0.343 & 132 & 78 \\
\hline / ог / & 0.423 & 144 & 78 \\
\hline | əo/ & 0.424 & 140 & 76 \\
\hline / av/ & 0.587 & 134 & 75 \\
\hline / Іә/ & 0.202 & 130 & 75 \\
\hline / eə/ & 0.107 & 115 & 73 \\
\hline / ৩ә / & 0.210 & 106 & 75 \\
\hline /егә/ & 0.180 & 105 & 76 \\
\hline / агә/ & 0.136 & 109 & 77 \\
\hline /ог/ & 0.154 & 150 & 77 \\
\hline /ə0ə/ & 0.149 & 132 & 75 \\
\hline / avə/ & 0.141 & 129 & 75 \\
\hline
\end{tabular}


https://doi.org/10.52834/jmr.v17i34.82

Table (21) : The analysis of the sounds for the native speaker

\begin{tabular}{|c|c|c|c|}
\hline Sound & Duration & $\mathrm{FO}$ in $(\mathrm{Hz})$ & Pitch \\
\hline$|\Lambda|$ & 0.165 & 122 & 76 \\
\hline$/ \mathrm{p} /$ & 0.195 & 149 & 72 \\
\hline /e / & 0.167 & 134 & 74 \\
\hline$|æ|$ & 0.186 & 126 & 73 \\
\hline / I / & 0.120 & 132 & 72 \\
\hline$|v|$ & 0.140 & 131 & 72 \\
\hline | o | & 0.103 & 145 & 74 \\
\hline / $3: /$ & 0.336 & 139 & 76 \\
\hline / u:/ & 0.219 & 143 & 76 \\
\hline / $0: /$ & 0.230 & 132 & 75 \\
\hline $\mid a: /$ & 0.295 & 129 & 74 \\
\hline / i: / & 0.132 & 137 & 77 \\
\hline$/ \mathrm{e}_{\mathrm{I}} /$ & 0.209 & 243 & 75 \\
\hline / $\mathrm{a}_{\mathrm{I}} /$ & 0.343 & 232 & 78 \\
\hline / ог / & 0.423 & 241 & 78 \\
\hline | əo/ & 0.424 & 340 & 76 \\
\hline | av/ & 0.587 & 334 & 75 \\
\hline / Іә/ & 0.202 & 230 & 75 \\
\hline / eə/ & 0.307 & 215 & 73 \\
\hline /vo / & 0.280 & 206 & 75 \\
\hline /ена/ & 0.270 & 305 & 76 \\
\hline / агә/ & 0.336 & 309 & 77 \\
\hline /ог/ & 0.254 & 233 & 77 \\
\hline /ə0ə/ & 0.449 & 403 & 75 \\
\hline / avə/ & 0.141 & 323 & 75 \\
\hline
\end{tabular}




\subsection{Data analysis}

The T-test is used to show whether there is any significant difference through the performance of all subjects for each word containing all English vowel sounds . It is also used to show whether there is any significant difference regarding the performance of all the subjects for each word containing English short vowels. And whether there is any significant difference regarding the performance of all the subjects for each word containing English diphthongs and triphthongs .

The level of significance is 0.05 for this research because according to $t$-test table, if there are twenty students performed in the test, 0.05 is the suitable level of significance to be used. The tabulated $t$-value at 0.05 with 21 degree of freedom is 1.96 (Walker, 1969:161) . The value which is 1.96 and over will be significant and values that are less than 1.96 will be non-significant .

The data were analyzed by( SPSS) Statistical Package for Social Sciences . By using SPSS, the researcher works out to find the Mean , Standard deviation , and the $t$-value. According to the first word (mud), eight students pronounced the word correctly / $m_{\Lambda} d / .12$ students couldn't pronounce the word correctly as it is pronounced by the native speaker . Seven students pronounce the second word (cot ) correctly as it is pronounced by the native speaker / kpt / . While thirteen students couldn't pronounce the word correctly.

Eight students pronounce the third word correctly ( wreck ) / rek/ while twelve students pronounce it in the wrong way. According to the word (flash), seven students pronounce it in the right pronunciation /flæ $/$ while thirteen students pronounce it incorrectly. Word number five (lift), seven students pronounce it correctly / I Ift / while thirteen students pronounce it in the wrong pronunciation . 


\section{هبلة أبحاث هيسان، المبد السابع عشر، العدد الرابع والثلاثون، كانون الأول، السنة 2021}

https://doi.org/10.52834/jmr.v17i34.82

The words ( shook, ago, heard ), six students pronounce them in the right way / fuk / /əgəə// and / ha:d / . Fourteen students couldn't pronounce them correctly. Through the pronunciation of the word (rude ), twelve students couldn't pronounce it correctly while eight students pronounce it in the right way /ru:d/ . Through the pronunciation of the words ( caught, calm ,steel, mate, and right ), nine students pronounce them correctly /ko:t / / ka:m/ and /sti:l/, / meIt/ and / rart/ while eleven students couldn't pronounce them correctly . One student pronounce this word correctly (quoit ) / koit / , whereas the others couldn't pronounce it correctly. According to the words (coat) and (loud ), seven students pronounce them in the right way / kəot/ and /laud/,while the others pronounce them incorrectly. The words (feared, cared, and moored ), four students pronounce them correctly /fird /, / keəd / and / moəd / whereas sixteen students couldn't pronounce them correctly

According to the first triphthong (layer ), four students pronounce it correctly / Іегә/ while sixteen students pronounce it incorrectly. The word (liar ), seven students pronounce it in the right way /laı /, whereas thirteen students couldn't pronounce it correctly .The words (loyal, lower , and tower), six students pronounce them in the right way / loıl / , / ləoə/ , and /tavə / while fourteen students pronounce them incorrectly .

Table (22) : Means, Std Deviation and T-value of the words containing all English vowels

\begin{tabular}{|c|c|c|l|l|l|}
\hline \multirow{2}{*}{ No. } & \multirow{2}{*}{ Mean } & \multirow{2}{*}{$\begin{array}{c}\text { Std } \\
\text { Deviation }\end{array}$} & \multicolumn{2}{|c|}{ Value } & Significance \\
\cline { 4 - 5 } & & $\begin{array}{l}\text { Calculated } \\
\mathrm{t}-\text { value }\end{array}$ & $\begin{array}{l}\text { Tabulated } \\
\text { T-Value }\end{array}$ & \\
\hline 1 & 1.543 & 0.366 & 1.534 & 1.96 & sig. \\
\hline
\end{tabular}


https://doi.org/10.52834/jmr.v17i34.82

\begin{tabular}{|c|c|c|c|c|c|}
\hline 2 & 1.642 & 0.233 & 2. 899 & 1.96 & sig. \\
\hline 3 & 1.543 & 0.366 & 1.534 & 1.96 & sig. \\
\hline 4 & 1.642 & 0.233 & 2. 899 & 1.96 & sig. \\
\hline 5 & 1.642 & 0.233 & 2. 899 & 1.96 & sig. \\
\hline 6 & 1.756 & 0.272 & 3.776 & 1.96 & sig. \\
\hline 7 & 1.756 & 0.272 & 3.776 & 1.96 & sig. \\
\hline 8 & 1.756 & 0.272 & 3.776 & 1.96 & sig. \\
\hline 9 & 1.543 & 0.366 & 1.534 & 1.96 & sig. \\
\hline 10 & 1.888 & 0.355 & 4.576 & 1.96 & sig. \\
\hline 11 & 1.888 & 0.355 & 4.576 & 1.96 & sig. \\
\hline
\end{tabular}


https://doi.org/10.52834/jmr.v17i34.82

\begin{tabular}{|c|c|c|c|c|c|}
\hline 12 & 1.888 & 0.355 & 4.576 & 1.96 & sig. \\
\hline 13 & 1.888 & 0.355 & 4.576 & 1.96 & sig. \\
\hline 14 & 1.888 & 0.355 & 4.576 & 1.96 & sig. \\
\hline 15 & 1.687 & 0.355 & 2.231 & 1.96 & sig \\
\hline 16 & 1.642 & 0.233 & 2. 899 & 1.96 & sig. \\
\hline 17 & 1.642 & 0.233 & 2. 899 & 1.96 & sig. \\
\hline 18 & 1.901 & 0.333 & 0.132 & 1. 96 & sig. \\
\hline 19 & 1.901 & 0.333 & 3.132 & 1. 96 & sig. \\
\hline 20 & 1.901 & 0.333 & 3.132 & 1.96 & sig. \\
\hline
\end{tabular}


https://doi.org/10.52834/jmr.v17i34.82

\begin{tabular}{|l|l|l|l|l|l|}
\hline 21 & 1.901 & 0.333 & 3.132 & 1.96 & sig. \\
\hline 22 & 1.642 & 0.233 & 2.899 & 1.96 & sig. \\
\hline 23 & 1.756 & 0.272 & 3.776 & 1.96 & sig. \\
\hline 24 & 1.756 & 0.272 & 3.776 & 1.96 & sig. \\
\hline 25 & & & & & \\
\hline
\end{tabular}

— percentages of correct answers

- percentages of incorrect answers

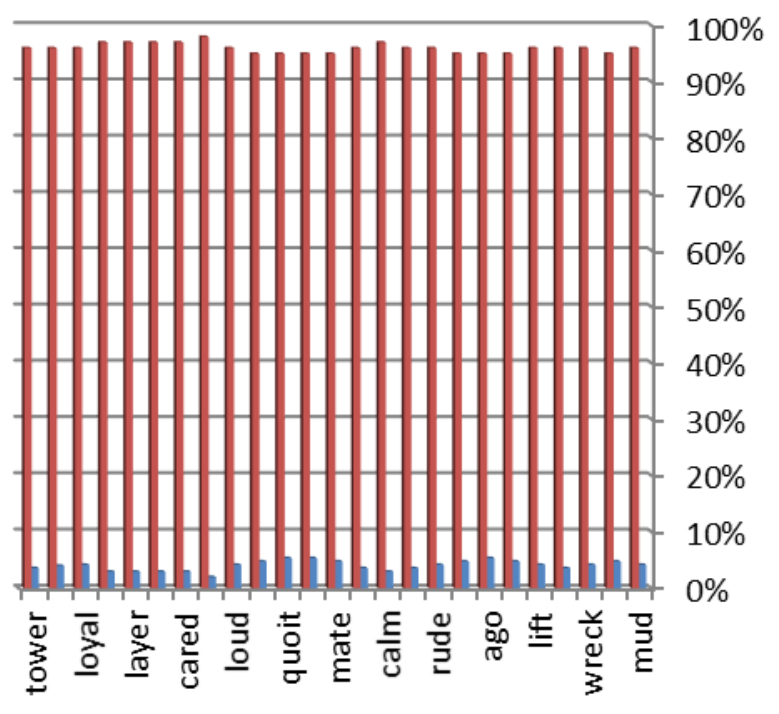




\section{هجلة أبحاث هيسان، الجبد السابع عشر، العدد الرابع والثلاثون، كانون الأول، السنة 2021}

https://doi.org/10.52834/jmr.v17i34.82

Figure (7) Histogram of the Subjects' performance in pronouncing words containing all the English vowels

Table (23) : Means, Std Deviation and T-value of words containing pure vowels

\begin{tabular}{|c|c|c|c|c|c|}
\hline \multirow{2}{*}{ No. } & \multirow{2}{*}{ Mean } & \multirow{2}{*}{$\begin{array}{c}\text { Std } \\
\text { Deviation }\end{array}$} & \multicolumn{2}{|r|}{$\mathrm{T}-$} & \multirow{2}{*}{ Significance } \\
\hline & & & $\begin{array}{l}\text { Calculated } \\
\text {--value }\end{array}$ & $\begin{array}{c}\text { Tabulated } \\
\text { T-Value }\end{array}$ & \\
\hline 1 & 1.543 & 0.366 & 1.534 & 1.96 & sig. \\
\hline 2 & 1.642 & 0.233 & 2. 899 & 1.96 & sig. \\
\hline 3 & 1.543 & 0.366 & 1.534 & 1.96 & sig. \\
\hline 4 & 1.642 & 0.233 & 2. 899 & 1.96 & sig. \\
\hline & 1.642 & 0.233 & 2. 899 & & \\
\hline
\end{tabular}


هبلة أبحاث هيسان، الجبد السابع عشر، العدد الرابع والثلاثون، كانون الأول، السنة 2021

https://doi.org/10.52834/jmr.v17i34.82

\begin{tabular}{|c|c|c|c|c|c|}
\hline 5 & & & & 1.96 & sig. \\
\hline 6 & 1.756 & 0.272 & 3.776 & 1.96 & sig. \\
\hline 7 & 1.756 & 0.272 & 3.776 & 1.96 & sig. \\
\hline \multirow[t]{2}{*}{8} & & & & & \\
\hline & 1.756 & 0.272 & 3.776 & 1.96 & sig. \\
\hline \multirow[t]{2}{*}{9} & & & & & \\
\hline & 1.543 & 0.366 & 1.534 & 1.96 & sig. \\
\hline \multirow[t]{2}{*}{10} & & & & & \\
\hline & 1.888 & 0.355 & 4.576 & 1.96 & sig. \\
\hline \multirow[t]{2}{*}{11} & & & & & \\
\hline & 1.888 & 0.355 & 4.576 & 1.96 & sig. \\
\hline \multirow[t]{2}{*}{12} & & & & & \\
\hline & 1.888 & 0.355 & 4.576 & 1.96 & sig. \\
\hline
\end{tabular}




\section{هبلة أبحاث هيسان، المبلد السابع عشر، العدد الرابع والثلاثون، كانون الأول، السنة 2021}

https://doi.org/10.52834/jmr.v17i34.82
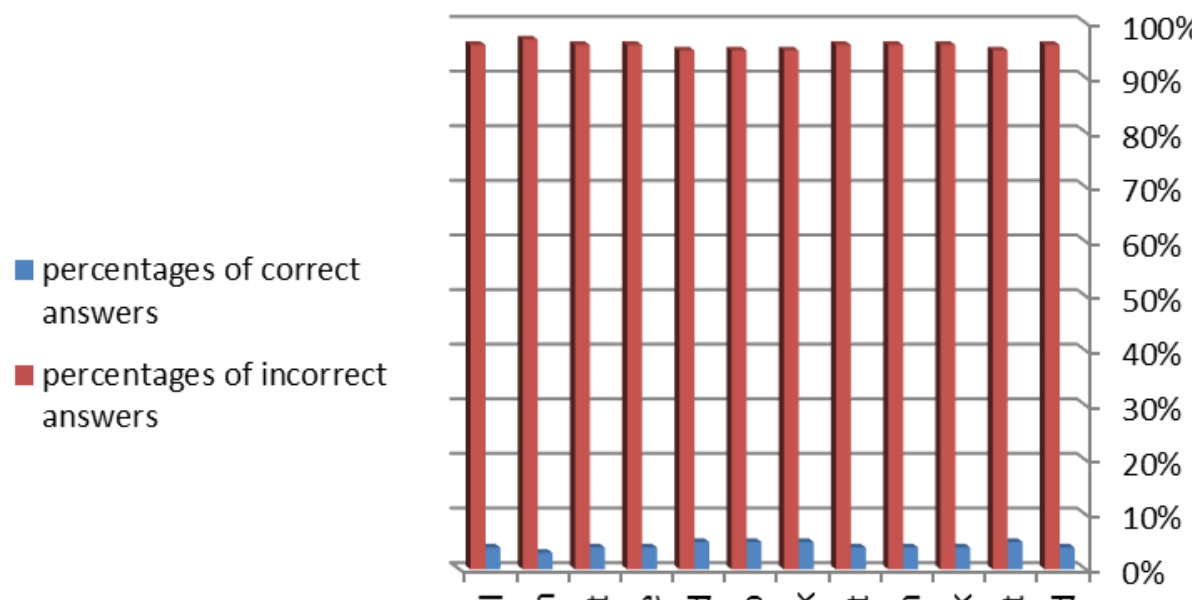

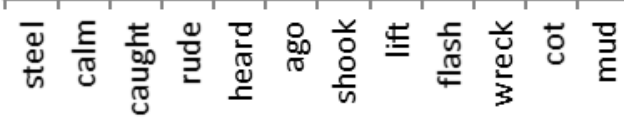

Histogram of the Subjects' performance in pronouncing words containing pure vowels Figure(8)

Table (24) : Means , Std Deviation and T-value of words containing diphthongs and triphthongs

\begin{tabular}{|c|c|c|c|c|c|}
\hline \multirow{2}{*}{ No. } & \multirow{2}{*}{ Mean } & \multirow{2}{*}{$\begin{array}{c}\text { Std } \\
\text { Deviation }\end{array}$} & \multicolumn{2}{|c|}{ Value } & \multirow{2}{*}{ Significance } \\
\hline & & & $\begin{array}{l}\text { Calculated } \\
\text { t-value }\end{array}$ & $\begin{array}{l}\text { Tabulated } \\
\text { T-Value }\end{array}$ & \\
\hline 1 & 1.888 & 0.355 & 4.576 & 1.96 & sig. \\
\hline 2 & 1.888 & 0.355 & 4.576 & 1.96 & sig. \\
\hline
\end{tabular}


https://doi.org/10.52834/jmr.v17i34.82

\begin{tabular}{|c|c|c|c|c|c|}
\hline 3 & 1.687 & 0.355 & 2.231 & 1.96 & sig. \\
\hline 4 & 1.642 & 0.233 & 2. 899 & 1.96 & sig. \\
\hline 5 & 1.642 & 0.233 & 2. 899 & 1.96 & sig. \\
\hline 6 & 1.901 & 0.333 & 2.132 & 1.96 & sig. \\
\hline 7 & 1.642 & 0.233 & 2.889 & 1.96 & siq. \\
\hline 8 & 1.901 & 0.333 & 3.132 & 1.96 & sig. \\
\hline 9 & 1.901 & 0.333 & 3.132 & 1. 96 & sig. \\
\hline 10 & 1.901 & 0.333 & 3.132 & 1.96 & sia \\
\hline
\end{tabular}




\section{هبلة أبحاث هيسان، المبلد السابع عشر، العدد الرابع والثلاثون، كانون الأول، السنة 2021}

https://doi.org/10.52834/jmr.v17i34.82

\begin{tabular}{|c|c|c|c|c|c|}
\hline 11 & 1.642 & 0.233 & 2.899 & 1.96 & sig \\
\hline 12 & 1.756 & 0.272 & 3.776 & 1.96 & sig. \\
\hline 13 & 1.756 & 0.272 & 3.776 & 1.96 & sig. \\
\hline
\end{tabular}

uercentages of correct answers

a percentages of incorrect answers

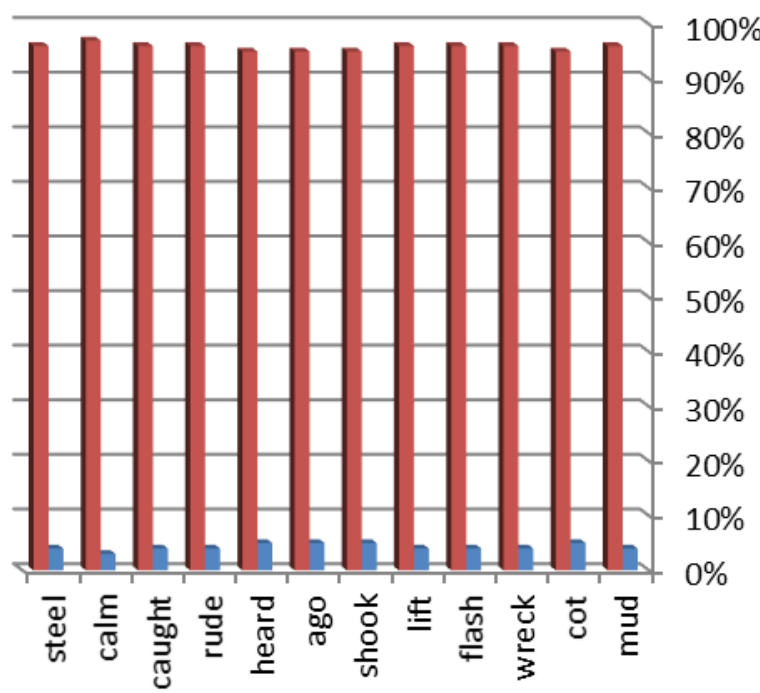

Figure (9) Histogram of the Subjects' performance in pronouncing words containing diphthongs and triphthongs

Through the analysis of data, it seems that the students face difficulty is pronouncing all the vowel sounds . The achievement is found to be statistically significant because the calculated $t-$ value is higher than the tabulated $t-v a l u e$. The data presented here provide a strong confirmation with the first hypotheses because 


\section{1 كانون الأول، السنة}

https://doi.org/10.52834/jmr.v17i34.82

the students find difficulty in pronouncing all the English vowels. The data also provide a strong confirmation with the second hypothesis because the students find difficulty in pronouncing English diphthongs and triphthongs more than pure vowels because of the nonexistence of many diphthongs and triphthongs in Arabic language .

One main problem faced by Iraqi learners is that spelling contribute to some pronunciation errors . Arabic orthographic system is shallow. This means that each letter is in relationship with the sound . The sound is pronounced as it is written . English has a deep orthography system in which the relationship between the letters and sounds is not a one to one relationship. Each letter in spelling has more than one pronunciation. For example, the letter ' o ' in some words like ( some, move, home, woman ) has different sounds in pronunciation $/ \Lambda, \mathrm{u}$, , ə,, , I $/$. So, the English learners who don't have the mastery of pronunciation will face difficulty in pronouncing these vowel sounds. The letter (a) in (water, same, fat ) as another example has more than one pronunciation / ๑: , e,,$æ /$. If the learner has no knowledge about this inconsistency, this will lead to mispronunciation . So, most linguists connect the pronunciation problems of vowels with the complexity of the English vowels system and the inconsistency of its pronunciation .

There is another problem is that there is conflict between the sound systems of English and Arabic . Iraqi learners of English form habits of their mother tongue (Arabic ) so they build the phonological features of Arabic through the pronunciation of English words.This leads to mispronunciation .The non-existence of many diphthongs and triphthogs in Arabic language leads to difficulty in pronunciation .

Another problem is the different numbers of vowels in English and Arabic . This causes mispronunciation. English has 25 vowel sounds ( 7 short vowels, 5 long vowels, 8 diphthongs, and 5 triphthongs). Arabic has 6 pure vowels and 2 diphthongs . 


\section{Conclusion}

Since the aim of the study is to encounter the problems faced by Iraqi learners of English in pronouncing English vowel sounds, the researcher comes to the conclusion that there are several matters affect the students in pronouncing English words. The first matter is that sound systems of English and Arabic are different in many ways. English vowel sounds are different from Arabic vowel sounds in number, in the way they are produced, and even many English vowels don't exist in Arabic sound system. The second matter is the mother tongue interference. Complexity of vowel systems for the two languages (English and Arabic) can be considered as the third matter . The forth matter is the spelling system and its effect

on

pronunciation

In order to solve these problems, language laboratories could be of a great help in teaching language .Learners could listen to recordings of English native speakers and then to try to imitate them .

Appendix

Pronounce the following words -

$1-$ mud

2-right

3-steel

$4-$ calm

5-cot 
هبلة أبحاث هيسان، الجبد السابع عشر، العدد الرابع والثلاثون، كانون الأول، السنة 2021

\section{https://doi.org/10.52834/jmr.v17i34.82}

6-layer

7-loyal

8-mate

9-quoit

10-rude

11-flash

12-lift

13-heard

14-lower

15-cared

16-moored

17-shook

18-ago

19-caugh

20-loud

21-feared

22-liar

23-tower

24-coat

\section{References}


Abercrombie , D . (1967) . Elements of General phonetics . Edinburgh :Edinburgh University press

Birjandi , P and Nodaoushan , M .A. (2005) . An Introduction to phonetics . Iran : Tehran University Press .

Carr , P . (1993) . A Glossary of phonology . Edinburgh : Edinburgh University Press

Casas , R.M. (2014) . Readings in English phonetics and phonology . Inmaculade Arboleda-Guirao (eds)

Cruttenden , A . (2014) - Gimson's Pronunciation of English .New York : Routledge

Crystal , D.(2008) . A Dictionary of linguistic and phonetics, $6^{\text {th }}$ Edition . Oxford :Blackwell publishing .

Daniel , I . O. (2011) . Introducing phonetics and phonology of English . Cambridge Scholars publishing

De , A . (1999) . Handbook of the International phonetic Association : A

Guide to the use of the International phonetic Alphabet . Cambridge :Cambridge University press .

Gieferich , H.J. (1992) . English phonology : An introduction . New York : Cambridge University press

Katamba , F . (1989) . An Introduction to phonology .London : Longman Low , E . (2015) . Pronunciation for English as an International language. Routledge .

Roach , P · (2001) . Phonetics . Oxford : Oxford University Press 


\section{هجلة أبحاث هيسان، الجبد السابع عشر، العدد الرابع والثلاثون، كانون الأول، السنة 2021}

\section{https://doi.org/10.52834/jmr.v17i34.82}

Shandera , P and Burleigh , B . (2011) . A Mannual of English phonetics and phonology . London : North.Holland Publishing company

Seith , J and Dhamija , P.(2006) . A course in phonetics and spoken

English, $2^{\text {nd }}$ Edition . New Delhi :Prentic Hall of India

Walker, H.M and Lev , J. (1969) . Elementary Statistical

Methods. New York : New York Press 